Human and Animal Health

Vol.59: e16160299, January-December 2016 http://dx.doi.org/10.1590/1678-4324-2016160299 ISSN 1678-4324 Online Edition

BRAZILIAN ARCHIVES OF BIOLOGY AND TECHNOLOGY

AN INTERNATIONAL JOURNAL

\title{
The Dynamic of some Biochemical Indicators at Species of Medicinal Plants from Areas of Suceava County, Romania, Emerged under the Mining Pollution Influence
}

\author{
Elena Todirascu-Ciornea ${ }^{\mathbf{1}}$; Gabriela Dumitru ${ }^{{ }^{*}}$. \\ ${ }^{I}$ Alexandru Ioan Cuza University, Biology Bvd. Carol I, Romania.
}

\begin{abstract}
It is known the fact that the mining causes huge damages on the environment having negative biologic effects extremely severe on some groups of organisms of the food chain. The pollutants causes major damages at the level of leaves' cuticles, the vegetation reacting through irreversible modifications at the tissue's level and at substances and energy metabolism, like a riposte to the apparition of the stress induced by the ROS, stress that creates real disturbances on physiological and biochemical processes. Considering the fact that, on the one hand, the activity of oxidoreductases is strongly influenced by the presence of the pollutants factors, with direct effect on the oxidative's stress production, and on the other hand that the plants react at ROS accumulation, through self-protection and adaptability mechanisms, the aim of this study consisted in monitoring the activity of some oxidoreductases in the leaves of plantain and mint species harvested in 2015 from different mining areas of Suceava County. In parallel was determined the dehydrogenase activity of the soil, the samples being collected from the same areas subdued to anthropic pollution, using like reference swatch, samples from Putna. The obtained results signalize the accumulation of some quantities highly arisen by free radicals of oxygen at investigated species, the enzymatic activity being significantly higher in the mining plant comparatively to the control areal. The microbial dehydrogenases from the soil samples were remarked through different activities based on the types of heavy metals that pollute each harvesting area and on the deepness profile.
\end{abstract}

Key words: oxidative stress; mint; plantain; pollution

*Authors for correspondence: gabriela.dumitru@uaic.ro 


\section{INTRODUCTION}

The Plantago major L. ssp. major and Mentha longifolia L. species belong to Lamiales order, the Plantaginaceae and Lamiaceae families, having a series of unique properties that recommend them for their using in the alternative traditional and modern medicine. Plantago major (plantain) is a semi-harvested plant originary from North America, Europe and Asia ${ }^{1}$, the cultivations from the hole world making use for, long millennia, the plantain leave to help to the amelioration for different types of diseases.

The main components of the plantain are the iridoides glycosides (specially the aucubin), the mucilages and the tans, which have the role to reduce irritation and to „burke" the harmful organisms, conferring to it, in the same time, also expectorant properties ${ }^{2}$. Moreover, the specie is rich in polysaccharides, emulsions, pectin, saponin, salicylic acid $^{3}$, carboxylic phenolic acids (derivates of the caffeic acid), rutin, morin, quercetin ${ }^{4}$, minerals (calcium, magnesium, zinc, sodium, potassium) ${ }^{5}$, alkaloids, terpenoids ${ }^{6}$, vitamin $\mathrm{C}$, antioxidant and anti-inflammatory agents ${ }^{3,7-10}$.

The plantain leaves present significant antiinflammatory, antihemorrhagic, hematopoietic, analgesic ${ }^{3}$, antioxidant, anti-carcinogen ${ }^{11,12}$, antitumoral ${ }^{8,9}$, anti-febrile, immuno-modulators and anti-hypertensive 13-16, anesthetic, antiviral, astringent, antihelmintic, analeptic, antihistaminic, antireumatic and diuretic effects ${ }^{17,18}$.

The specialty literature highlights, in the same time, the particular role that plantain has in the hypercholesterolemia, hyperglycemia's treatment and as laxative agent ${ }^{19}$, in the treatment of flues, hepatitis, skin diseases and infectious, in the problems related to digestive organs, respiratory organs, of reproduction and circulation ${ }^{3}$. Other authors ${ }^{20-23}$ signalize the using with success of these species in the neutralizing of intern and extern toxins, the ethanolic extracts being able to generate anti-cough effects comparatively with those of the codeine ${ }^{24}$. Studying the commercial aspects of the Plantago gender species, Weryszko-Chmielewska ${ }^{25}$ highlighted the particular antiviral effect of the phenolic compounds, isolated from the Plantago major leaves, especially on the multiplication stages of HIV-1, HIV-2 and ADV-3.

Mentha longifolia $\mathrm{L}$. is an aromatic evergreen nectarifer plant, significant rich in essential oils (piperitone, piperitenone oxide, piperitone epoxides, 1,8-cineole, pulegone, sabinene and $\alpha$ - pinene) that confer to this one an antimicrobial, antioxidant, antispasmodic and high citotoxic potential ${ }^{26}$.

Numerous studies indicate the antioxidant role ${ }^{27}$, antimutagenic, anticarcinogen, digestive, antiviral and anti-inflammatory of respiratory pathways, the species being used in the pharmaceutical industry, of the tobacco, alimentary and cosmetically ${ }^{28,29}$. Alamgeer Akhtar et al. ${ }^{30}$ emphasize the significant antihypertensive role of the wild mint extracts, but also in the treatment of cardiac and stomachal affections, diarrhea and dysenteries, while, AlBayati 31 and Al-Rawashdeh 28 signalize antipruritic, antiseptic and stimulatory properties, as well as the role of this plant in the minor pains of the mouth up to the neck's irritations, nasal decongestive, wrenches, rheumatism, dyspnea, hysteria and menstrual pain.

Ghasemi et al. ${ }^{32}$ highlight the influence of essential oils obtained from mint in the preventing of growth of some bacteria and recommend, in the same time, their using in the treatment of different types of diseases. In the same time, Heydari et al. ${ }^{33}$ advance the problem of the bacteria increasing resistance to synthetic antibiotics and propose the possibility of their substitution with natural products, the Mentha longifolia essential oils being an example in this sense.

A worthily remark to keep in mind would be the one that a lot of medicinal plants have the ability of stockpiling and translocating at the root, stem and leaves level, toxic metals as $\mathrm{Cr}, \mathrm{Mn}, \mathrm{Fe}, \mathrm{Cu}, \mathrm{Zn}$ and $\mathrm{Pb}$, putting into danger therefore the consumers' health ${ }^{34}$, the literature data 35 signalizing, furthermore the fact that the heavy metals are accumulated in the soil, sediments and, from here, in plants and animals, including the human organism. In this sense, in the last years the deposing of heavy metals in plants, as a result of anthropical activities, it was increased more and more the attention on inorganic pollution assigning the plants the role of passive bio-monitors ${ }^{36}$.

The aim of this study was the evaluation of the anthropic impact on the activity of some oxidoreductases from leaves and soil, at species of plants harvested from different mining areas of the Suceava County (Mountain County with a $8553.5 \mathrm{~km}^{2}$ surface, situated in the north-eastern of Romania at the frontier with Ukraine).

\section{MATERIAL AND METHODS}




\section{Sample Collection}

The investigations were done on samples of foliar tissue taken in May, July and September 2015, from Mentha longifolia and Plantago major ssp. major exemplars emerged under the anthropic pollution's influence. The sampling was done in the approachement of the mining plant of the uranium Crucea-Botuşana, Oiţa-Ciocăneşti area (manganese exploitation), in the vicinity of the preparation factory of the cupriferous ores Fundu Moldovei and Putna area (control area). As well, in the aim of determining the dehydrogenase's potential of the soil, were taken samples from two deepness profiles $(0-20 \mathrm{~cm}$ and $20-40 \mathrm{~cm})$ from the four areas anterior mentioned.

The Determination of Biochemical Parameters The dosage of the superoxid-dismutase activity (SOD, E.C. 1.15.1.1) was done through the Winterbourn method which consists in the capacity of this enzyme to inhibit nitroblue tetrazolium reduction by superoxide anions generated after riboflavin photo reduction ${ }^{37}$. Catalase (CAT, E.C. 1.11.1.6) and the peroxidase (POX, E.C. 1.11.1.X.) were determined through Sinha spectophotometrical method and the ortodianisidine method, while, for the activity of foliar dehydrogenases was used the trifenil-tetrazolium method. For the evaluation of specific enzymatic activity, which restores in the most thrusty way the real catalytical capacity of the enzymes, was dosed apart the concentration of soluble total proteins through Bradford method ${ }^{37}$. The soil's microbiological activity, evaluated through the actual and potential dehydrogenasic activity, was highlighted through Casida method ${ }^{38}$.

\section{Statistical Analysis}

For each specie and biochemical parameter apart, were realized each three parallel determinations, and the results drowned graphically represent the average of those repetitions \pm standard deviation. The differences between control and the samples obtained from polluted areas were compared with the Student t-test using standard statistical packages (the results being considered significant if the $p$ value was less than 0.05).

\section{RESULTS AND DISCUSSION}

The mining activity represents one of the human preoccupations with negative impact on the environment quality, the natural ecosystems being deeply affected, mostly through the destruction of the flora and of the fauna with preponderance in the vicinity of the sterile dumps, but also of the ponds 39. The mining impact varies from the physical destruction of the habitat, accompanied by the biodiversity resources reduction, up to the pollutants accumulation in different areals of the environment ${ }^{40}$.

It is known that the environment pollution exerts a permanent stress on the vegetable tissues, to counteract the harmful action of the stressor factors, the plants being under the necessity of developing firm protection systems, enzymatic and nonenzymatic. Furthermore, the impact of the heavy metals' toxicity at vegetable level is due to generating of the oxygen reactive species (ROS) and to induction of the so called oxidative stress ${ }^{41}$, this one's debut in plants imposing a reorganization of the cellular metabolism in its assembly. The inchoate stages of the answer determine the so called "the alarm phase", and the later stages (the acclimatization phase) are associated with the de novo biosynthesis of some proteins with protective role against the stress (the antioxidant enzymes) and other compounds (carotenoids, tocoferols, osmoprotectors-prolin), following that, in the recovery period, to be activated the degradation processes of these protector compounds and a stabilization of the new cellular homeostasis ${ }^{42}$.

SOD is an oxidoreductase implied in the antioxidant defensive which catalyze the dismutation reaction of the superoxidic radicals, having a crucial role in the removal of the toxic effect of free radicals ${ }^{43}$.

At Plantago major ssp. major, harvested from the Putna areal, an important touristy region situated in the north of Suceava County, the SOD activity varies between $6.773 \pm 0.891 \mathrm{USOD} / \mathrm{mg}$ protein in September and $8.803 \pm 1.008 \mathrm{USOD} / \mathrm{mg}$ protein in July (Fig. 1). In the case of the samples harvested from the vicinity of the mining plant of manganese (Oiţa-Ciocăneşti), respectively of the cupriferous ores (Fundu Moldovei), there aren't ascertained significant differences in what concerns the SOD activity, being remarked certain variations function of the month in which was realized the harvest. Thus, in May 2015, were ascertained medium values of $9.629 \pm 1.162 \mathrm{USOD} / \mathrm{mg}$ protein (Fundu Moldovei), respectively $9.9 \pm 0.969$ USOD/mg protein (Oiţa-Ciocăneşti), in July $8.689 \pm 0.927$ $\mathrm{USOD} / \mathrm{mg}$ protein and $8.581 \pm 0.833 \mathrm{USOD} / \mathrm{mg}$ protein, while in September, the enzyme layed out 
the lowest activity, reaching values of $8.235 \pm 0.82$ $\mathrm{USOD} / \mathrm{mg}$ protein and $8.551 \pm 0.85 \mathrm{USOD} / \mathrm{mg}$ protein.

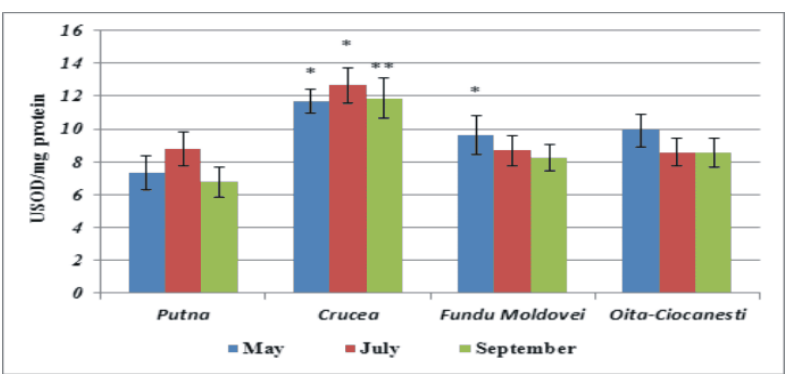

Figure1. SOD activity in Plantago major.

$* * * \mathrm{p}<0.001$ (very significant); ** $0.001<\mathrm{p}<0.005$ (significant);

* $0.01<\mathrm{p}<0.05$ (less significant); $0.05<\mathrm{p}<0.5$ (not significant)

Significant differences $(0.001<\mathrm{p}<0.005)$ and less significant $(0.01<\mathrm{p}<0.05)$ by comparison with the reference, are ascertained in the case of the samples harvested from the vicinity of the uranium mining from Crucea-Botuşana, the enzyme activity reaching the maximum level of activity in July $(12.659 \pm 1.008 \mathrm{USOD} / \mathrm{mg}$ protein). Besides, the specialty literature ${ }^{44}$ signalizes the fact that the uranium may be translocated from the environment at the plants level, where it glitches the mechanism of the antioxidant defensive, the effect of this metal at foliar level being translated through the increasing of SOD and CAT activity.

At Mentha longifolia L., the SOD activity is, commonly, higher comparatively with that decelated at Plantago major L. (Fig. 2), at the samples harvested from Crucea area the enzyme laying out medium values between $11.561 \pm 1.664$ USOD/mg protein (September) and 18.1 \pm 1.008 USOD/mg protein (in July). In the areas of manganese exploitation and of cupriferous ores, the mint presents a comparable SOD activity. In May, the enzyme reaches the level of $10.339 \pm 1.074$ USOD/mg protein at Fundu Moldovei and $10.227 \pm 1.222 \mathrm{USOD} / \mathrm{mg}$ protein in Oița-Ciocăneşti area, while, in July and September there are ascertained values slightly higher at the samples from the vicinity of the copper mining exploitation $(11.188 \pm 0.702 \quad \mathrm{USOD} / \mathrm{mg}$ protein and $10.343 \pm 1.398 \mathrm{USOD} / \mathrm{mg}$ protein, comparatively with $10.376 \pm 1,35$ and $9.906 \pm 1.017 \mathrm{USOD} / \mathrm{mg}$ protein).The apply of the $t$ statistical signification test emphasized the existence of some differences less significant $(0.01<p<0.05)$ between the reference samples and those from Crucea area harvested in May and September, respectively strongly significant $(p<0.001)$ at those harvested in July from the same areas.

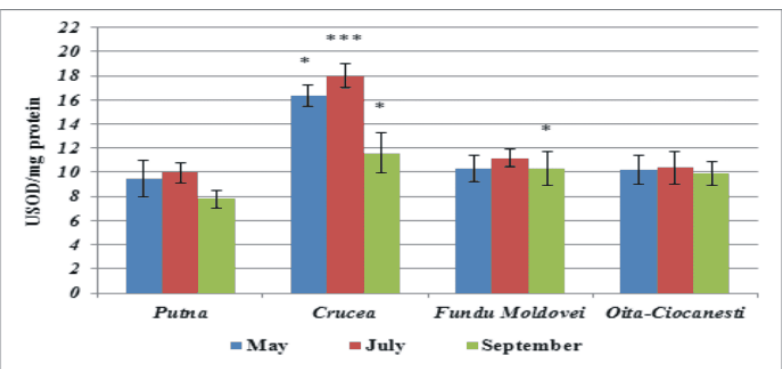

Fig. 2. SOD activity in Mentha longifolia

$* * * \mathrm{p}<0.001$ (very significant); ** $0.001<\mathrm{p}<0.005$ (significant);

* $0.01<\mathrm{p}<0.05$ (less significant); $0.05<\mathrm{p}<0.5$ (not significant)

The CAT is a key enzyme in the induction of the plants' tolerance to stress, recent studies showing that the high activity of this one is essential for the survival of the vegetable organisms in moderate metallic stress conditions, at values strongly increased, the deterioration of the enzyme being irreversible ${ }^{45}$.

Our results show the fact that the presence of the uranium wastes, cupriferous ores and of the manganese in the soil determine a strong oxidative stress at the level of the foliar apparatus of Plantago major L. species, the CAT activity being considerable increased in the polluted areas comparatively with the reference area. If in the Putna areal (Fig. 3), where the mineral resources are represented with preponderance of $\mathrm{spa}^{46}$, the activity of this oxidoreductase varies between $9.347 \pm 0.994 \mathrm{UC} / \mathrm{mg}$ protein (September) and $11.691 \pm 1.144 \mathrm{UC} / \mathrm{mg}$ protein (July), at OițaCiocăneşti the enzyme reaches a level of 2.5 times approximately higher, at Fundu Moldovei of 1.4 times higher in September and of 2.6 times higher in May and July, while, at the samples taken from the vicinity of the uranium mine from Crucea, CAT lays out an activity of 4 times higher (no matter the period of harvest). The Student test indicated significant differences $(0.001<p<0.005)$ and strongly significant $(\mathrm{p}<0.001)$ between the control samples and those harvested from the areas bended to the mining pollution, excepting the harvested plot in September, from the vicinity of the cupriferous ores exploitation from Fundu Moldovei. The specialty literature ${ }^{47,48}$ signalizes the fact that the high pollution in this area is due to the presence of the coarse wastes of $\mathrm{Fe}$ and $\mathrm{S}$ (as 
main elements), but also $\mathrm{Cu}, \mathrm{Zn}, \mathrm{Pb}, \mathrm{Cd}, \mathrm{Cr}, \mathrm{As}, \mathrm{Ni}$, $\mathrm{Co}$ and $\mathrm{Ca}$, the risks particularly high, after the closing of the mine, being dued to the fragility of the tailing pond Dealu Negru.

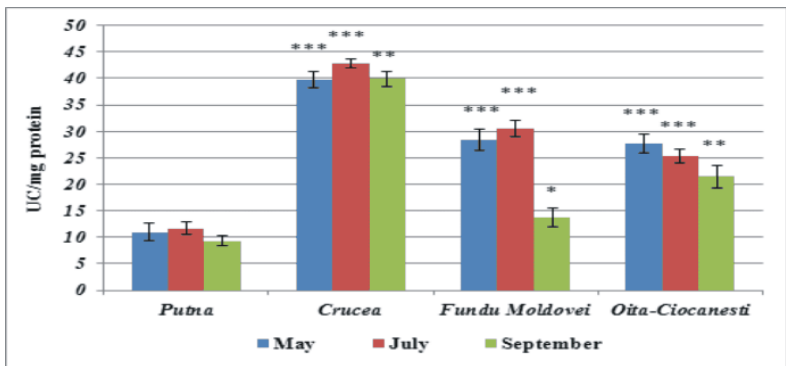

Fig. 3. CAT activity in Plantago major

$* * * p<0.001$ (very significant); ** $0.001<\mathrm{p}<0.005$ (significant);

* $0.01<\mathrm{p}<0.05$ (less significant); $0.05<\mathrm{p}<0.5$ (not significant)

To explain the results it must be taken into account the fact that the CAT activity is influenced by different environmental conditions as the low temperature or excessive, the intensity too high of light, the drought stress and the presence of heavy metals etc., which have as results the intensification of ROS production in the plants tissues ${ }^{49}$. In the same time, in the temperate areas, the environmental factors vary in large limits fact that determines that the antioxidant system of the species from these areas to play an essential role in their acclimatization ${ }^{50}$. Nandita and Prasant Kumar ${ }^{51}$ signalize the direct influence of the manganese on the CAT and POX increase activity in plants, and Karimi et al. ${ }^{52}$ highlights the manganese and copper effect, in different concentrations, on the SOD, CAT and POX intensification at the leaves and roots level.

The literature data ${ }^{53,54}$ show the antioxidant properties of the wild mint which confer to this one a significant account both for human as for the pharmaceutical industry.

Also at this species it can be remarked significant differences in what concerns the CAT activity between the polluted areas and that of reference (Fig. 4), the maximal medium values registering, also this time, at the samples taken from the vicinity of the uranium mine exploitation $(35.428 \pm 2.061$ $\mathrm{UC} / \mathrm{mg}$ protein in May, 38.121 $\pm 1.938 \mathrm{UC} / \mathrm{mg}$ protein in July and $32.141 \pm 1.926 \mathrm{UC} / \mathrm{mg}$ protein in September 2015). Also in the case of the samples derived from Fundu Moldovei and Oița-Ciocăneşti, CAT follows the same trend, excepting the harvested plot, in September, from the vicinity of the manganese mine from Oița, where the enzyme lays out values more approached whit those decelated in the control area $12.004 \pm 1.842 \mathrm{UC} / \mathrm{mg}$ protein, respectively $9.961 \pm 1.541 \mathrm{UC} / \mathrm{mg}$ protein). The statistical analyze highlights prominent differences between the reference samples and those derived from the mining plots.

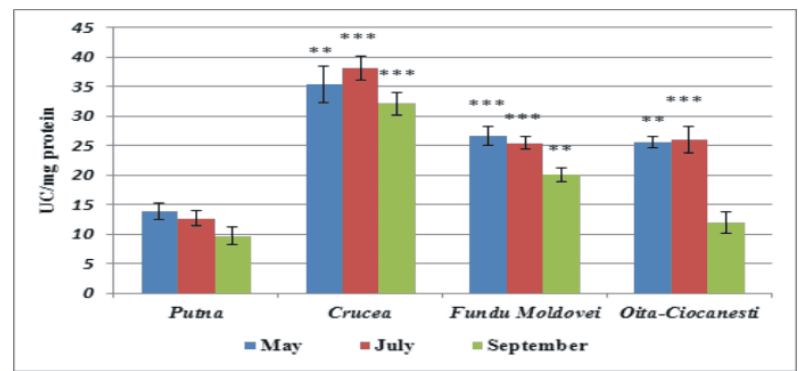

Fig. 4. CAT activity in Mentha longifolia

$* * * \mathrm{p}<0.001$ (very significant); ** $0.001<\mathrm{p}<0.005$ (significant);

* $0.01<\mathrm{p}<0.05$ (less significant); $0.05<\mathrm{p}<0.5$ (not significant)

Our results concords with those from the scientific literature that signalize a strong ROS accumulation and, implicitly, a CAT activity's increase at species derived from uranium polluted environments ${ }^{55}$. In the same time, the prominent differences of enzymatic activity could be explain by the seasonal variations, but also zonals, of the hydric level, the hydric regime potencying the forming process of the superoxidic radical, fact that has as consequence a sustained SOD activity and, implicitly, of CAT that block the hydrogen peroxide accumulation ${ }^{56,57}$. On the other hand, the lower catalasic activity signalized at Mentha longifolia L., comparatively with Plantago major L., can be explained by the genetic background and the species specificity, but also by the epigenetic adjustment through the interaction with environmental factors ${ }^{58}$.

POX is an oxidoreductase with mainly role in the defense of the vegetable organisms against the biogenic stress and the abiotic stress, it being able to be associated with a high number of essential metabolic processes like the cells' elongation, their lignification, the phenolic oxidation, the growth and the morphogenesis processes ${ }^{59-62}$, modifications of this enzyme's activity taking place in the modulation processes of cellular differences and of tissues' development ${ }^{63}$.

At Plantago major L. species, samples harvested in May, POX' $s$ activity reach the maximum level at the samples derived from Crucea area, while, at those harvested at Fundu Moldovei, the activity 
represents $52.68 \%$ from this one, at OițaCiocăneşti $60.16 \%$, and at Putna, only $43.29 \%$ (Fig. 5). Remarkable is the fact that the maximal enzymatic values are registered at Crucea in May (19.341 $\pm 2.01 \mathrm{UP} / \mathrm{mg}$ protein), at Fundu Moldovei in July (12.091 $\pm 1.636 \mathrm{UP} / \mathrm{mg}$ protein), and at OiţaCiocăneşti in September $(12.463 \pm 1.305 \mathrm{UP} / \mathrm{mg}$ protein) in strongly correlation with the thermal regime and of the precipitations from the respective zones.

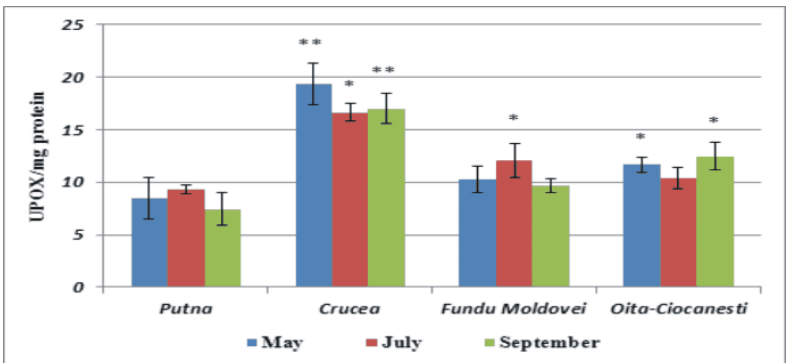

Fig. 5. POX activity in Plantago major

$* * * p<0.001$ (very significant); ** $0.001<\mathrm{p}<0.005$ (significant);

* $0.01<\mathrm{p}<0.05$ (less significant); $0.05<\mathrm{p}<0.5$ (not significant)

If in the CAT case, the statistic signification's test emphasized differences strongly significant between the mining areas and that of control, POX manifests a behavior slightly different, between these areas observing significant differences (Crucea area May and September $-0.001<\mathrm{p}<0.005$ ) and less significant or even insignificant for the rest. Džamić et al. ${ }^{64}$ and Bahtiti ${ }^{65}$ demonstrate the antioxidant and antifungal capacity of Mentha longifolia, the different extracts and essential oils being of big interest both for the fundamental scientist as well for the food industry, due to the possibility of their using as natural additives which may replace the synthetic antioxidants.

In the Crucea mining area, POX lays out values that oscillate between $14.887 \pm 1.259 \mathrm{UP} / \mathrm{mg}$ protein (in September) and $19.797 \pm 1.118 \mathrm{UP} / \mathrm{mg}$ protein (in May), while, at the samples harvested from the reference area, the enzymatic activity is a lot lower, the variation interval being contained between $8.204 \pm 0.496 \mathrm{UP} / \mathrm{mg}$ protein (at the beginning of the autumn) and $10.384 \pm 1.046 \mathrm{UP} / \mathrm{mg}$ protein (during the summer). The statistical analyze of the experimental data obtained shows significant and strongly significant differences $(p=0.0005)$ between the activity of this oxidoreductase from the samples taken from the two areas. At the taxons derived from the vicinity of the cupriferous ores and manganese exploitations, the enzymatic activity presents slightly variations from month to month, reaching levels of the same order of size for each area in part $(8.826 \pm 1.02 \mathrm{UP} / \mathrm{mg}$ protein $11.748 \pm 2.212 \mathrm{UP} / \mathrm{mg}$ protein, respectively $8.781 \pm 1.716 \mathrm{UP} / \mathrm{mg}$ protein and $11.458 \pm 0.854$ $\mathrm{UP} / \mathrm{mg}$ protein).

The differences enough significant available in function of the harvest period of the vegetable tissues, may be put on the fact that the activity of the different types of POX izoenzymes are in direct correlation with the growth stage, the seasonal period in which, the temperature and other stress parameters like flowering, go pale and the fall of the leaves ${ }^{49}$. Moreover, the increase of POX activity was proved to be a prompt answer to the accumulation of free radicals formed as a consequence of the induced stress by the presence of the environmental pollution, thus insuring the cells resistance against to this one's accumulation and mediating the plants adaptability to the stressor factors ${ }^{66}$.

Complementary to the tests related to the antioxidant defense was opted in favor of determining the main enzymes activity of Krebs cycle, being known the fact that an acclimatization of the plants to the stressor factors' presence is associated with deep changes at the level of substances' and energy's metabolism, with role in the increasing of the vegetable organisms' resistance at the stress induced by the metalliferous excess.

In what concerns the izocitrat-dehydrogenase (IDH) activity in the samples derived from the Crucea-Botuşana area, there are observed medium values which oscillate between $45.271 \pm 0.917$ and $54.16 \pm 0.99 \mu \mathrm{g}$ formazan $/ \mathrm{g}$ vegetable tissue at Plantago major, respectively $37.805 \pm 1.28$ and $52.744 \pm 2.292 \mu \mathrm{g}$ formazan/g vegetable tissue at Mentha longifolia (Figs. 7-8), these values being strongly significant $(\mathrm{p}<0.001)$ to comparison with those registered in the reference area (between $13.424 \pm 1.194$ and $24.001 \pm 2.36 \mu \mathrm{g}$ formazan $/ \mathrm{g}$ vegetable tissue at plantain, respectively $13.841 \pm 1.412$ and $20.255 \pm 1.215 \mu \mathrm{g}$ formazan/g vegetable tissue at mint, in September, respectively July). At the samples from Fundu Moldovei and Oiţa-Ciocăneşti, IDH registers the maximum value of activity in July, both at plantain (34.149 and $39.074 \mu \mathrm{g}$ formazan $/ \mathrm{g}$ vegetable tissue) as well as at the wild mint (25.66 and $24.252 \mu \mathrm{g}$ formazan/g vegetable tissue), in strong connection also with the temperatures excessively high and the decreasing 
hydric level registered in this month. On the other hand, there must be taken into account the fact that the IDH - NADPH dependent is implied in the cellular senescence ${ }^{67}$, the NADPH present in the peroxizoms being adjusted by this enzyme, fact that confers it a direct role in the supplying with the reduced form of the nicotine-amidic coenzyme, necessary in the mitochondria antioxidant protection.

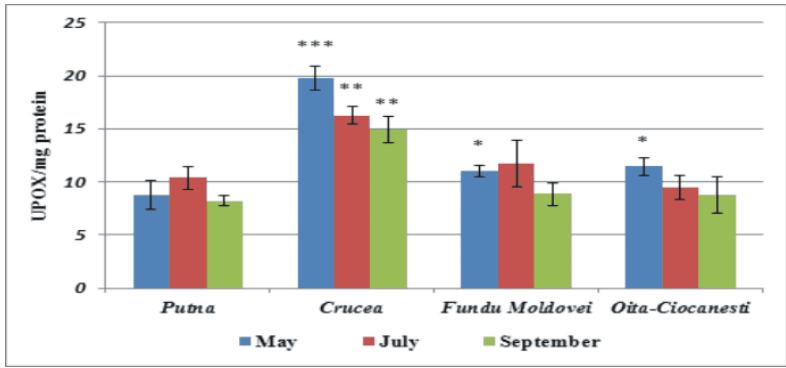

Fig. 6. POX activity in Mentha longifolia

$* * * \mathrm{p}<0.001$ (very significant); ** $0.001<\mathrm{p}<0.005$ (significant);

* $0.01<\mathrm{p}<0.05$ (less significant); $0.05<\mathrm{p}<0.5$ (not significant)

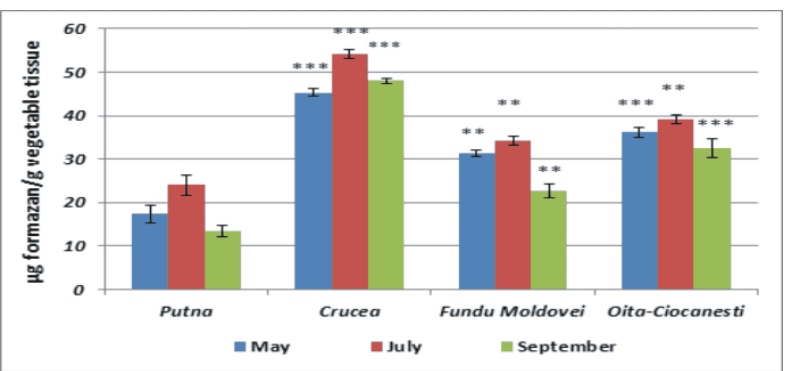

Fig. 7. IDH activity in Plantago major

$* * * \mathrm{p}<0.001$ (very significant); $* * 0.001<\mathrm{p}<0.005$ (significant);

* $0.01<\mathrm{p}<0.05$ (less significant); $0.05<\mathrm{p}<0.5$ (not significant)

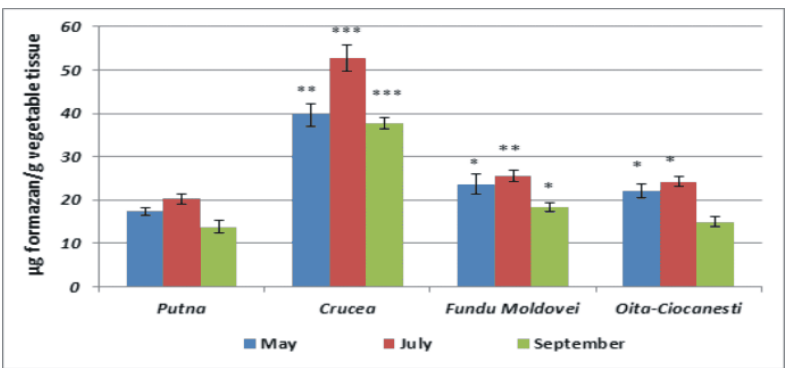

Fig. 8. IDH activity in Mentha longifolia

$* * * \mathrm{p}<0.001$ (very significant); $* * 0.001<\mathrm{p}<0.005$

(significant);

* $0.01<\mathrm{p}<0.05$ (less significant); $0.05<\mathrm{p}<0.5$ (not significant)
The $\alpha$-ketoglutarat dehydrogenase (KDH) is the enzyme responsible of the conversion of $\alpha$ ketoglutarat into succinil-CoA, at the species analyzed by us, the IDH activity being secondated by much lower $\mathrm{KDH}$ activity, both at the plantain as at the mint. Thus, in the Crucea areal, the enzyme reaches, at Plantago major (Fig. 9), values contained between the variation limits of 30.628 $48.249 \mu \mathrm{g}$ formazan/g vegetable tissue, at Fundu Moldovei between $20.641-30.142 \mu \mathrm{g}$ formazan $/ \mathrm{g}$ vegetable tissue, while, in the reference areal (Putna) the activity doesn't overtake $20.56 \pm 0.847$ $\mu \mathrm{g}$ formazan/g vegetable tissue (in July).

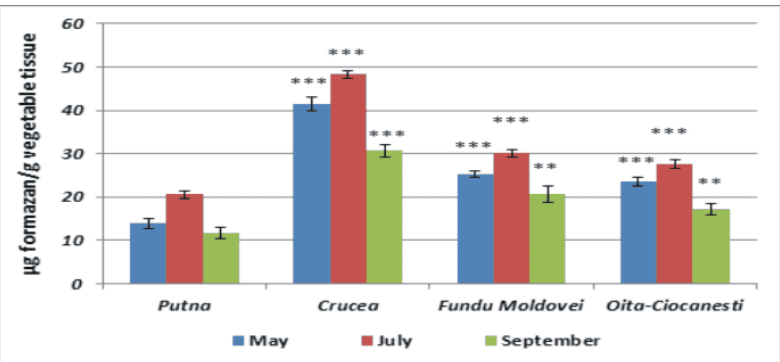

Fig. 9. KDH activity in Plantago major

$* * * \mathrm{p}<0.001$ (very significant); ** $0.001<\mathrm{p}<0.005$ (significant);

* $0.01<\mathrm{p}<0.05$ (less significant); $0.05<\mathrm{p}<0.5$ (not significant)

This fact could be explain through that a part of the substratum there is possible to enter in the anabolism channels connected in this point, in function of the vegetable tissue's necessities. More than this, the $\alpha$-ketoglutarat may be a target for ROS generated at mitochondrial level, the vegetable cell being able to run away an oxidative anti-stress strategy, so as to maintain the cellular mitochondria integrity for the proper intermediary metabolism and for the extension of the cellular viability.

Excepting the values registered for the $\mathrm{KDH}$ activity in September, at Mentha longifolia, for the plots derived from the vicinity of the copper and manganese mines from Fundu Moldovei and OiţaCiocăneşti, where the differences of activity towards the control area are less significant $(0.01<\mathrm{p}<0.05)$, at all the samples the apply of the Student test demonstrated, for the two species, the existence of some significant differences $(0.001<\mathrm{p}<0.005)$ and strongly significant $(\mathrm{p}<0.001)$ comparatively with the areal considerate unpolluted.

At Plantago major, the succinat dehydrogenase activity (SDH) is slightly increase, comparatively with the Mentha longifolia species, the specialty 
literature ${ }^{68}$ signalizing the fact that, besides the succinic acid resulted or degraded on the Krebs cycle way, this compound can be generated or catabolized also on other metabolic ways, the succinat, alongside with the citrate, ftalat, tartrat, salicylat and acetate proving to be excellent chelators due to their fast mobility and to metals' assimilation by the plants from the polluted areas. The plantain lays out, in May (Fig. 11), values of the SDH activity which oscillates from $16.014 \pm 1.509 \mu \mathrm{g}$ formazan $/ \mathrm{g}$ vegetable tissue (Putna), at approximately $26 \mu \mathrm{g}$ formazan $/ \mathrm{g}$ vegetable tissue (Fundu Moldovei and OiţaCiocănești) and, respectively, 32.798 $\pm 2.531 \mu \mathrm{g}$ formazan/g vegetable tissue (Crucea), while, in September, the minimum activity was decelated, also this time, in the reference area $(11.463 \pm 0.753$ $\mu \mathrm{g}$ formazan/g vegetable tissue), value approached with that one highlighted in the vicinity of the Oiţa manganese mining plant $(13.845 \pm 1.652 \mu \mathrm{g}$ formazan/g vegetable tissue). In July, $\mathrm{SDH}$ reaches major values at the Fundu Moldovei plot (31.997 $\pm 1.663 \mu \mathrm{g}$ formazan $/ \mathrm{g}$ vegetable tissue) and Crucea $(38.058 \pm 2.384 \mu \mathrm{g}$ formazan/g vegetable tissue).

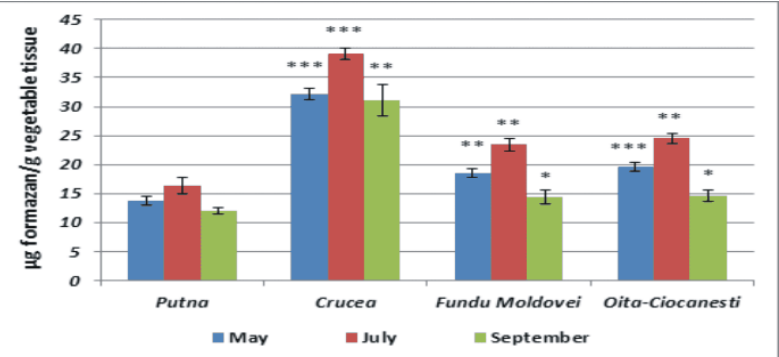

Fig. 10. KDH activity in Mentha longifolia

$* * * \mathrm{p}<0.001$ (very significant); ** $0.001<\mathrm{p}<0.005$ (significant);

* $0.01<\mathrm{p}<0.05$ (less significant); $0.05<\mathrm{p}<0.5$ (not significant)

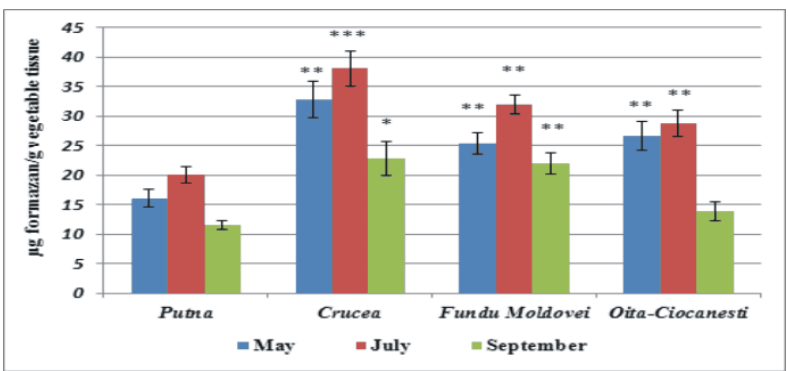

Fig. 11. SDH activity in Plantago major

$* * * p<0.001$ (very significant); ** $0.001<\mathrm{p}<0.005$ (significant);

* $0.01<\mathrm{p}<0.05$ (less significant); $0.05<\mathrm{p}<0.5$ (not significant)
The analyze of experimental results concerning the SDH activity highlights at Mentha longifolia (Fig. 12) the same distribution of the value palette from an area to another, the activity being only slightly lower comparatively with the Plantago major species, only in the Oiţa-Ciocăneşti samples case ascertaining differences more ample in May and September $(16.337 \pm 1.991$ and $20.773 \pm 2.04 \mu \mathrm{g}$ formazan/g vegetable tissue at mint, comparatively with $26.674 \pm 2.516$ and $13.845 \pm 1.652 \mu \mathrm{g}$ formazan/g vegetable tissue at plantain).

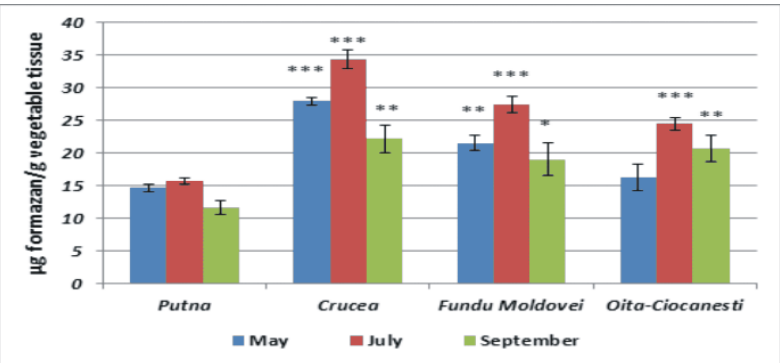

Fig. 12. SDH activity in Mentha longifolia

$* * * \mathrm{p}<0.001$ (very significant); ** $0.001<\mathrm{p}<0.005$ (significant);

$* 0.01<\mathrm{p}<0.05$ (less significant); $0.05<\mathrm{p}<0.5$ (not significant)

The values levels of the malat dehydrogenase's activity (MDH) at the studied taxons show a balanced deployment of the tricarboxilic acids' cycle, the enzyme presenting variation limits rather ample, the registered activity being approached of that one remarked in the SDH case. The high threshold of $\mathrm{MDH}$, especially in the Crucea areal, certifies a significant toxicity of the uranium and of the radionuclides from the area upon the foliar material, being known the fact that a high quantity of malat is strongly correlated with a high activity of phosphoenolpiruvat carboxilase, enzyme implied in the main cellular metabolism during the stomatal opening and in the malic acid input as a respiratory substratum ${ }^{69,70}$ in the vegetable tissues exposed at the different stress conditions.

If in the Putna area the MDH activity varies, at the plantain (Fig. 13), between 13.679 and $17.116 \mu \mathrm{g}$ formazan/g vegetable tissue, in the vicinity of the mines from Fundu Moldovei and Oiţa-Ciocăneşti reaches maximal valoric thresholds of approximately $25 \mu \mathrm{g}$ formazan/g vegetable tissue (in July), while, in the Crucea areal, the activity is extremely high in May (35.631 $\pm 1.224 \mu \mathrm{g}$ formazan/g vegetable tissue) and July (36.025 $\pm 2.054 \mu \mathrm{g}$ formazan/g vegetable tissue). At Mentha longifolia (Fig. 14), MDH comports major 
differences, the maximum enzymatic activity being remarked at the taken plot from Fundu Moldovei (29.315 $\pm 0.762 \mu \mathrm{g}$ formazan/g vegetable tissue), followed by the one from Crucea $(25.439 \pm 1.808 \mu \mathrm{g}$ formazan/g vegetable tissue) and Oiţa-Ciocăneşti (21.551 $\pm 1.35 \mu \mathrm{g}$ formazan/g vegetable tissue).

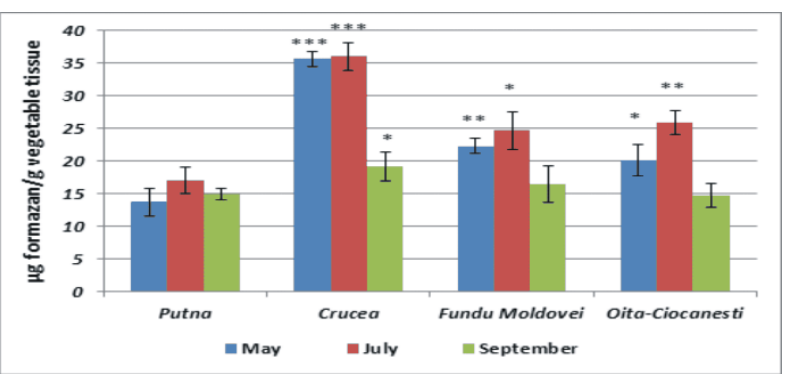

Fig. 13. MDH activity in Plantago major

$* * * \mathrm{p}<0.001$ (very significant); ** $0.001<\mathrm{p}<0.005$ (significant);

* $0.01<\mathrm{p}<0.05$ (less significant); $0.05<\mathrm{p}<0.5$ (not significant)

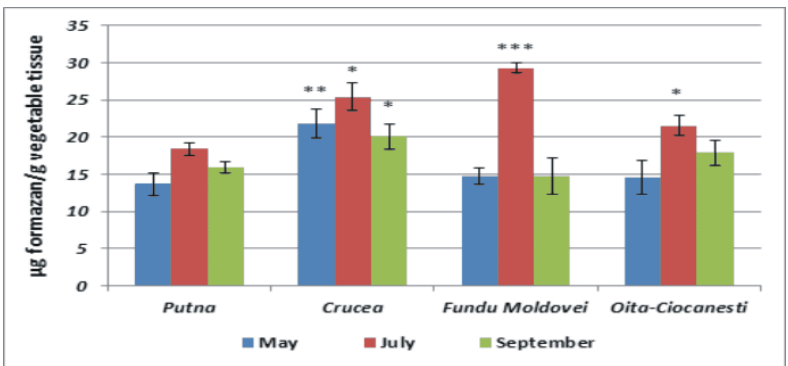

Fig. 14. MDH activity in Mentha longifolia

$* * * \mathrm{p}<0.001$ (very significant); ** $0.001<\mathrm{p}<0.005$ (significant);

* $0.01<\mathrm{p}<0.05$ (less significant); $0.05<\mathrm{p}<0.5$ (not significant)

The statistical analyze highlights significant strongly differences between the Plantago major taxons harvested in May $(p=0.00034)$ and July $(p=0.00038)$ from Crucea area comparatively with the reference sample and between the Mentha longifolia plots taken in July, from Fundu Moldovei comparatively with the control plot $(p=0.00008)$.

The literature data ${ }^{71}$ signalize the fact that the enzymatic activity of the soil and the proliferation of the microorganisms from soil constitute the most efficient indicators of the stability and fertility of the ecosystems from the soil's level, the enzymes reacting immediately at any perturbation appeared at this level. From all the types of enzymes existing in the soil, the dehydrogenases (DH) constitute the most representative oxidoreductases, assuring the correct order of all the anabolic and catabolic reactions of the biogeochemical cycles of the soil ${ }^{72}$.
Taking into account the fact that the global microbiologic activity of the soil, and implicitly the DH activity - as biomarker of the degradation and reparation processes, are strongly influenced by a series of biotic and abiotic factors as the mining, the time and the temperature of incubation, the type of soil, the season, the loosening/aeration degree of the soil, its $\mathrm{pH}$, the humidity, the management and maintenance practices ${ }^{73-77}$, the soil's fertilization, the deepness profile of the soil, the presence of different heavy metals etc. ${ }^{78-82}$, we resorted at the actual (Dha) and potential (Dha) dehydrogenase activity determination in soil samples taken from two different deepness profiles.

As it is ascertained in Figure 15, in May, DHa varies from 1.272 $\pm 0.244 \mu \mathrm{g}$ formazan/g soil in Fundu Moldovei area, at $1.351 \pm 0.11 \mu \mathrm{g}$ formazan/g soil in the vicinity of the uranium mine from Crucea and up to $3.238 \pm 0.289 \mu \mathrm{g}$ formazan/g soil in the reference zone, respectively $4.836 \pm 0.463 \mu \mathrm{g}$ formazan $/ \mathrm{g}$ soil at Oiţa-Ciocăneşti. In the soil samples taken in May from the superficial stratum $(0-20 \mathrm{~cm})$, the maximum threshold of activity was reached in Putna area $(3.459 \pm 0.504 \mu \mathrm{g}$ formazan $/ \mathrm{g}$ soil) and Oiţa-Ciocăneşti $\quad(3.422 \pm 0.36 \mu \mathrm{g}$ formazan/g soil), while, in autumn, DHa reached lower levels of activity, in Fundu Moldovei area, for example, the enzyme presenting a value of only $0.959 \pm 0.066 \mu \mathrm{g}$ formazan/g soil.

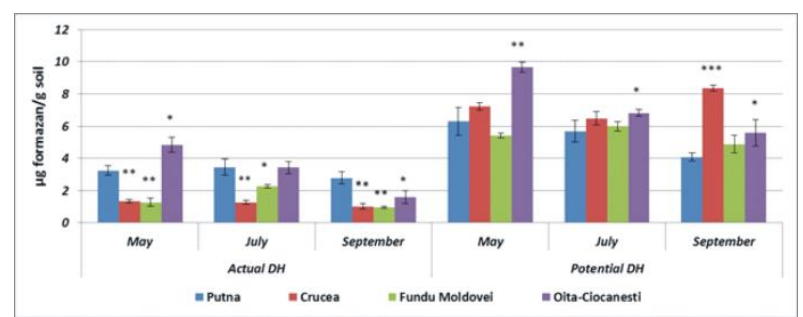

Fig. 15. Microbian DH activity in soil $(0-20 \mathrm{~cm})$

$* * * \mathrm{p}<0.001$ (very significant); ** $0.001<\mathrm{p}<0.005$ (significant);

* $0.01<\mathrm{p}<0.05$ (less significant); $0.05<\mathrm{p}<0.5$ (not significant)

To highlight more trusty the maximum potential of soil dehydrogenation, we determined the DHp activity as an index of the productivity and of the soil's microbial activity ${ }^{83}$. Thus, in the reference area, DHp lays out values which oscillate between $4.085 \pm 0.241 \mu \mathrm{g}$ formazan $/ \mathrm{g}$ soil in September and $6.308 \pm 0.854 \mu \mathrm{g}$ formazan/g soil in May, while, in the soil samples derived from the proximity of uranium and manganese mines, the activity varies from $6.474 \pm 0.414 \mu \mathrm{g}$ formazan/g soil (July) and 
8.36 $\pm 0.234 \mu \mathrm{g}$ formazan/g soil (September), respectively $5.593 \pm 0.813 \mu \mathrm{g}$ formazan $/ \mathrm{g}$ soil (September) and $9.658 \pm 0.331 \mu \mathrm{g}$ formazan/g soil (May).

The application of the Student test highlighted significant differences $(0.001<p<0.005)$ and strongly significant $(\mathrm{p}<0.001)$ between the reference area and the mining areals CruceaBotuşana and Oiţa-Ciocăneşti.

A series of authors specify the fact that the dehydrogenasic activity varies in function of the soil's deepness profile, in correlation with the aeration degree and the type of microbial colonies $75,84-86$

Our results concords with the specialty literature in the sense that, the dehydrogenasic activity decrease once with the deepness of the soil, values found, both for Dha as for DHp being visible smaller. Thus, at the samples harvested from Putna area (Fig. 16), DHa and DHp reach the maximum activity threshold in May $(1.984 \pm 0.124 \mu \mathrm{g}$ formazan/g soil, respectively $3.23 \pm 0.297 \mu \mathrm{g}$ formazan/g soil), while the minimum level was marked out at Oiţa-Ciocăneşti, in September $(0.647 \pm 0.092 \mu \mathrm{g}$ formazan/g soil - DHa and $1.581 \pm 0.238 \mu \mathrm{g}$ formazan/g soil - DHp).

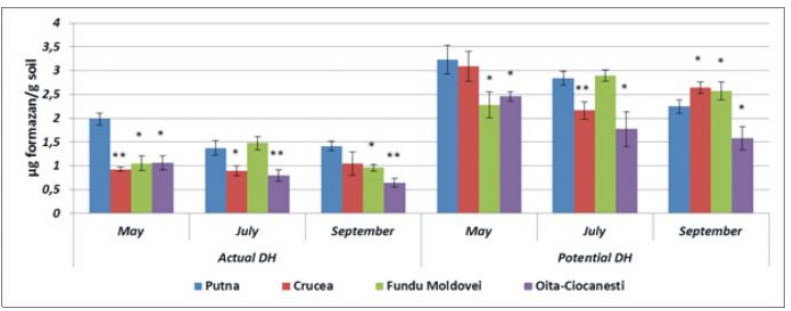

Fig. 16. Microbian DH activity in soil $(20-40 \mathrm{~cm})$

$* * * p<0.001$ (very significant); $* * 0.001<\mathrm{p}<0.005$ (significant);

* $0.01<\mathrm{p}<0.05$ (less significant); $0.05<\mathrm{p}<0.5$ (not significant)
To explain the obtained results it must be taken into account the multitude of factors which influence the DH activity, the type of soil, the thermal and hydric level, the aeration degree, the organic matter's availability and the anthropic activity's influence, having a marked impact on the bacteria that colonize the soils in case. Moreover, we used the glucose as a supplementary nutritive source, existing the possibility that certain microorganisms types to requires for the development another nutritive substratum that the one in case.

Accounting the DHp/Dha rapport comes out the fact that, both in the deep stratum as well in the superficial one, there are significant differences between the maximum action capacity of the microbial biomass and the dehydrogenasic activity at the determination moment (without nutritive substratum supplementary add), in the reference area the difference being of maximum 1.9 times higher in favor of the potential one (the superficial stratum - May). At the other pole there is the Crucea mining area, where the difference between the DHa and DHp activity is even of 8.15 times bigger for the surface stratum and of 3.22 times bigger in the one of profundity, while, at Fundu Moldovei the difference is of 5.09 times, respectively 2.68 times bigger (Tabel 1 ).

The specialty literature mentions the strong correlation that there is between the DH activity from the soil and the type of metals which pollute the respective areas, the uranium, the cadmium, the lead, the arsenium and the copper being through the most destructive ones on the microbiota ${ }^{86,87}$.

Table 1. Ratio $D H p / D H a$

\begin{tabular}{llllll}
\hline & Putna & Crucea & $\begin{array}{l}\text { Fundu } \\
\text { Moldovei }\end{array}$ & $\begin{array}{l}\text { Oita- } \\
\text { Ciocanesti }\end{array}$ \\
\hline \multirow{3}{\mathbf{0-20}\mathbf{~cm}}{} & May & 1.9481 & 5.3391 & 4.2555 & 1.9971 \\
& July & 1.6403 & 5.0976 & 2.6293 & 1.9903 \\
& September & 1.4636 & 8.1561 & 5.0991 & 3.5421 \\
& May & 1.6281 & 3.3286 & 2.1553 & 2.3154 \\
$\mathbf{2 0 - 4 0 ~ c m}$ & July & 1.9369 & 2.4109 & 1.9587 & 2.2271 \\
& September & 1.5857 & 2.5209 & 2.6871 & 2.4435 \\
\hline
\end{tabular}




\section{CONCLUSIONS}

Forasmuch the mining exploitation causes enormous damages at the environmental level, with extremely severe negative biologic effects on some important groups of organisms of the food chain, the phytoremediation process supposes, among others, the monitoring of some biochemical parameters at species from the contaminated sites, the vegetation reacting by irreversible physiological and biochemical modifications at the stress induced by the ROS.

The heavy metals' presence and of miscellaneous wastes resulted after the mining exploitation had a negative impact on the plants taken in study, the highest level of the oxidative stress being highlighted in the proximity of the uranium mine, SOD, POX and CAT having strongly significant activities comparatively with the harvested samples from the reference area (Putna), no matter the sampling period of the foliar material.

In what concerns the Krebs cycle's DH activity from the foliar tissues of Plantago major L., we can mention the existence of some strongly significant and significant differences between the harvested plots from the reference area and the mining areas Crucea-Botuşana, Fundu Moldovei and OiţaCiocăneşti, while, at Mentha longifolia L., prominent differences in function of the sampling place there are in the case of SDH (excepting May - Oiţa-Ciocăneşti area), while at IDH and KDH, the mining area Crucea stands out through activities allimportant comparatively with the control sample.

The analyze of experimental results concerning the dehydrogenasic activity of the soil, shows a different manner of behavior of these oxidoreductases, in function of the deepness profile, on the one hand, but also of the sampling place on the other hand, in strong correlation with the aeration degree of the soil, the different heavy metals which pollute a harvesting zone or another, but also the type of bacteria which colonize the soils in case and the possible differences in the bacterial physiology.

\section{REFERENCES}

1- Velasco-Lezama R, Tapia-Aguilar R, Roman-Ramos R, Vega Avila E, Perez-Gutierrez Ma S. Efffect of Plantago major on cell proliferation in vitro. $J$ Etnopharmacol. 2006; 103(1): 36-42.

2- Sarić-Kundalić B, Dobes C, Klatte-Asselmeyer V, Saukel J. Ethnobotanical study on medicinal use of wild and cultivated plants in middle, south and west
Bosnia and Herzegovina. J Ethnopharmacol. 2010; 131(1): 33-55.

3- Haddadian K, Haddadian K, Zahmatkash M. A review of Plantago plant. Indian J Tradit Know. 2014; 13(4): 681-685.

4- Vardapetyan H, Hovhannisyan D, Tiratsuyan S, Chailyan G. Quercetin content and antioxidant activity of armenian Crataegus Laevigata, Plantago Major and Artemisia Absinthium plants extracts. Journal of Experimental Biology and Agricultural Sciences. 2014; 2(2S): 220-225.

5- Ştef DS, Gergen I, Ştef L, Hărmănescu M, Pop C, Drugă M, Bujancă G, Popa M. Determination of the macro elements content of some medicinal herbs. Scientific Papers: Animal Science and Biotechnologies. 2010; 43(1): 122-126.

6- Chiang LC, Ng LT, Chiang W, Chang MY, Lin CC Immunomodulatory activities of flavonoids, monoterpenoids, triterpenoids, iridoid glycosides and phenolic compounds of Plantago species. Planta Med. 2003a; 69(7): 600-604.

7- Samuelsen AB. The traditional uses, chemical constituents and biological activities of Plantago major L. A review. J Etnopharmacol. 2000; 71: 1-21.

8- Pourmorad F, Hosseinimehr SJ, Shahabimajd N. Antioxidant activity, phenol and flavonoid contents of some selected Iranian medicinal plants. African $J$ Biotechnol. 2006; 5(11): 1142-1145.

9- Souri R, Amin G, Farsam H, Barazandeh Tehrani M. Screening of antioxidant activity and phenolic content of 24 medicinal plant extracts. DARU. 2008; 16(2): 83-87.

10- Nazaizadeh A, Mikaili P, Moloudizargari M, Aghajanshakeri S, Javaherypour S. Therapeutic uses and pharmacological properties of Plantago major L. and its active constituents. Journal of Basic and Applied Scientific Research. 2013; 3(9): 212-221.

11- Galvez M, Cordero MC, Cortes F, Ayus MY. Cytotoxic effect of Plantago spp. Oncancerallins. $J$ Etnopharmacol. 2003; 88: 125-130.

12- Srivastava V, Negi AS, Kuma JKR, Gupta MM, Khanuja SPS. Plant based anticancer molecules: A chemical and biological profile of some important leads. Bioorganic Med Chem. 2005; 13: 5892-5900.

13- Nunez-Guillen M, da Silva Emim J, Souccar C, Lapa A. Analgesic and antiinflammatory activities of the aqueous extract of Plantago major L. Int $J$ Pharmacogn. 1997; 35: 99-104.

14- Park K, Chang I. Anti-inflammatory activity of aucubin by inhibition of tumor necrosis factor-alpha production in RAW 264.7 cells. Planta Med. 2004; 70: 778-779.

15- Shim K, Choi S, Jeong M, Kang S. Effects of aucubin on the healing of oral wounds. In Vivo. 2007; 21: 1037-1042.

16- Zubair M, Nybom H, Lindholm C, Rumpunen K. Major polyphenols in aerial organs of greater plantain (Plantago major L.), and effects of drying 
temperature on polyphenol contents in the leaves. Sci Hortic-Amsterdam. 2011; 128(4): 523-529.

17- Matev M, Angelova I, Koichev A, Leseva M, Stefanov G. Clinical trial of a Plantago major preparation in the treatment of chronic bronchitis. Vitr. Boles. 1982; 21: 133-137.

18- Franca F, Lago EL, Marsden PD. Plants used in the treatment of leishmanial ulcers due to Leishmania (Viannia) braziliensis in an endemic area of Bahia. Brazil Rev Soc Bras Med Trop. 1996; 29: 229-232.

19- Jin CB, Noor HM. The hypoglycaemic effect of Plantago major leaf extract on alloxan-induced diabetic rats. Journal of Tropical Medicinal Plants. 2006; 7(2): 175-178.

20- Mc Cutcheon AR, Roberts TE, Gibbons E. Antiviral screening of British Colombian medicinal plants. $J$ Etnopharmacol. 1995; 49: 101-110.

21- Chiang LC, Chiang W, Chang MY, Lin CC. In vitro cytotoxic: antiviral and immunomodulatory effects of Plantago major and Plantago asiatica. Am J Chinese Med. 2003b; 31: 225-234.

22- Beara IN, Lesjak MM, Jovin ED, Balog KJ, Anackov GT, Orcic DZ et al. Plantain (Plantago L.) species as novel sources of flavonoid antioxidants. J Agric Food Chem. 2009; 57: 9268-9273.

23-Beara IN, Orcic DZ, Lesjak MM, Mimica-Ducik NM, Pekovik BA, Popovic MR, Liquid chromatography/tandem mass spectrometry study of antiinflamatory activity of plantain (Plantago L.) species. J Pharm BioMED Anal. 2010; 52: 701-706.

24- Boskabady MH, Rakhshandah M, Afiat Az, AelamiAmiri S. Antitussive effect of Plantago lanceolata in Guineea Pigs. IJMS. 2006; 31:3.

25- Weryszko-Chmielewska E, Matysik-Woźniak A, Sulborska A, Rejdak R. Commercially important properties of plants of the genus Plantago. Acta Agrobot. 2012; 65(1): 11-20.

26- Abedi R, Golparvar AR, Hadipanah A. Identification of the essential oils composition from four ecotypes of Mentha longifolia (L.) Huds. growing wild in Isfahan province, Iran. J BioSci Biotechnol. 2015; 4(2): 117-121.

27- Yumrutas O, Saygideger SD. Determination of antioxidant and antimutagenic activities of Phlomis armeniaca and Mentha pulegium. J Applied Pharmaceut Sci. 2012; 2: 36-40.

28- Al-Rawashdeh IM. Molecular taxonomy among Mentha spicata, Mentha longifolia and Ziziphora tenuior populations using the RAPD technique. Jordan Journal of Biological Sciences. 2011; 4(2): 63-70.

29- Al-Ali K, Abdelrazik M, Alghaithy A, Diab A, ElBeshbishy $\mathrm{H}$, Baghdadi $\mathrm{H}$. Antimutagenic and anticancer activity of Al Madinah Alhasawy mint (Mentha longifolia) leaves extract. Pakistan Journal of Biological Sciences. 2014; 17(12): 1231-1236.

30- Alamgeer Akhtar MS, Jabeen Q, Bashir S, Malik MNH, Khan HU, Rahman MSU et al.
Antihypertensive and toxicity studies of aqueous methanolic extract of Mentha longifolia L. The Journal of Animal \& Plant Sciences. 2013; 23(6): 1622-1627.

31- Al-Bayati FA. Isolation and identification of antimicrobial compound from Mentha longifolia L. leaves grown wild in Iraq. Annals of Clinical Microbiology and Antimicrobials. 2009; 8: 20.

32- Ghasemi M, Radjabalizade K, Gharari K, Yaghoobi $\mathrm{H}$, Asgarpoor D. Chemical composition and in vitro antibacterial activity of native Mentha longifolia essential oil from Ardabil, Iran on Streptococcus mutans, Lactobacillus rhamnosus and Actinomyces viscosus. Infect Epidemiol Med. 2016; 2(1): 11-14.

33- Heydari F, Saeedi S, Hassanshahian M. Antibacterial activity of Mentha longifolia against Salmonella typhimurium. Advanced Herbal Medicine. 2015; 1(3): 42-47.

34- Jena VK, Gupta S, Patel KS, Patel SC. Evaluating heavy metals contents in medicinal plant Mentha longifolia. J Mater Environ Sci. 2013; 4(3): 384-389.

35- Yabanlı M, Yozukmaz A, Sel F. Heavy metal accumulation in the leaves, stem and root of the invasive submerged macrophyte Myriophyllum spicatum L. (Haloragaceae): An example of Kadin Creek (Mugla, Turkey). Braz Arch Biol Technol. 2014; 57(3): 434-440.

36- Monaci F, Moni F, Lanciotti E, Grechi D, Bargagli R. Biomonitoring of airborne metals in urban environments: new tracers of vehicle emission, in place of lead. Environ Pollut. 2000; 107(3):321-327.

37- Cojocaru D. Enzimologie practică. Iasi: Ed. Tehnopress; 2009.

38- Drăgan-Bularda M. Microbiologie Generală. Lucrări practice. Cluj-Napoca: Universitatea Babeş-Bolyai; 2000.

39- Chibuike GU, Obiora SC. Heavy metal polluted soils: effect on plants and bioremediation methods. Applied and Environmental Soil Science. 2014; Article ID 752708, 12 pages, http://dx.doi.org/10.1155/2014/752708

40- Abdul-Wahab SA, Marikar FA. The environmental impact of gold mines: pollution by heavy metals. Cent Eur J Eng. 2012; 2(2): 304-313.

41- Schützendübel A, Polle A. Plant responses to abiotic stresses: Heavy metal-induced oxidative stress and protection by mycorrhization. J Exp Bot. 2002; 53: 1351-1365.

42- Kosova K, Vítámvás P, Prasil IT, Renaut J. Plant proteome changes under abiotic stress - Contribution of proteomics studies to understanding plant stress response. J Proteomics. 2011; 74(8): 1301-1322.

43- Lee MK, Arasu MV, Park S, Byeon DH, Chung SO, Park SU, et al. LED lights enhance metabolites and antioxidants in chinese cabbage and kale. Braz Arch Biol Technol. 2016; 59: e16150546, http://dx.doi.org/10.1590/1678-4324-2016150546. 
44- Saenen E, Horemans N, Vanhoudt N, Vandenhove $\mathrm{H}$, Biermans G, Van Hees M, et al. Effects of $\mathrm{pH}$ on uranium uptake and oxidative stress responses induced in Arabidopsis thaliana. Environ Toxicol Chem. 2013; 32(9): 2125-2133.

45- Sharma I, Ahmad P. Catalase: A Versatile Antioxidant in plants. In: Ahmad P, editor. Oxidative damage to plants: antioxidant networks and signaling. Elsevier Inc. 2014. p. 131-138.

46- Cocerhan C. Bazinul râului Suceava pe teritoriul României - Valorificarea potenţialului turistic. $\mathrm{PhD}$. University of Bucharest: Romania. 2012.

47- Balaban SI, Iancu OG, Bulgariu D. The geochemical distribution of heavy metals for some mine tailings from the Fundu Moldovei area, Romania. Carpath $J$ Earth Env. 2011; 6(2): 279-288.

48- Stumbea D. the flanks of the Dealul Negru tailings pond (Fundu Moldovei) - pollution risk factors. Carpath J Earth Env. 2013; 8(3): 103-112.

49- Zolfaghari R, Hosseini SM, Korori SAA. Relantionship between peroxidase and catalase with metabolism and environmental factors in Beech (Fagus orientalis Lipsky) in three different elevations. International Journal of Environmental Sciences. 2010; 1(2): 243-252.

50- Tuteja N, Gill SS. Plant acclimation to environmental stress. New York: Springer Science and Business Media; 2015.

51- Nandita J, Prasant Kumar B. Evaluation of biochemical indicators of iron and manganese contamination for sunflower plants: chlorophyll content, catalase and peroxidase. Asian Journal of Microbiology, Biotechnology \& Environmental Sciences Paper. 2012; 14 (2): 305-307.

52- Karimi P, Khavari-Nejad RA, Niknam V, Ghahremaninejad F, Najafi F. The effects of excess copper on antioxidative enzymes, lipid peroxidation, proline, chlorophyll, and concentration of $\mathrm{Mn}, \mathrm{Fe}$, and $\mathrm{Cu}$ in Astragalus neo-mobayenii. The Scientific World Journal.

2012; http://dx.doi.org/10.1100/2012/615670.

53- Elansary HO, Ashmawy NA. Essential oils of mint between benefits and hazards, J Essent Oil Bear Pl. 2013; 16(4): 429-438.

54- Ertaş A, Gören AC, Haşimi N, Tolan V, Kolak U. Evaluation of antioxidant, cholinesterase inhibitory and antimicrobial properties of Mentha longifolia subsp. noeana and its secondary metabolites. Rec Nat Prod. 2015; 9(1): 105-115.

55- Horemans N, Van Hees M, Van Hoeck A, Saenen E, De Meutter T, Nauts R, et al. Uranium and cadmium provoke different oxidative stress responses in Lemna minor L. Plant Biol. 2015; 17 (s1): 91-100.

56- Kumar Kar R. Plant responses to water stress. Role of reactive oxygen species. Plant Signal Behav. 2011; 6(11): 1741-1745.

57- Bolat I, Dikilitas M, Ercisli S, Ikinci A, Tonkaz T. The effect of water stress on some morphological, physiological, and biochemical characteristics and bud success on apple and quince rootstocks. The Scientific World Journal. 2014; Article ID 769732, http://dx.doi.org/10.1155/2014/769732.

58- Samokhvalov V, Ignatov V, Kondrashova $M$. Inhibition of Krebs cycle and activation of glyoxylate cycle in the course of chronological aging of Saccharomyces cerevisiae. Compensatory role of succinate oxidation. Biochimie. 2004; 86(1): 39-46.

59- Passardi F, Cosio C, Penel C, Dunand C. Peroxidases have more functions than a Swiss army knife. Plant Cell Rep. 2005; 24: 255-265.

60- Marjamaa K, Kukkola ME, Fagerstedt VK. The role of xylem class III peroxidases in lignification. J Exp Bot. 2008; 60(2): 367-376.

61- Díaz-Tiaels Carla, Graña Elisa, Reigosa J. Manuel, Sánchez-Moreiras M. Adela. The role of peroxidases on the mode of action of chalcone in Arabidopsis roots. Plant Signal Behav. 2012; 7(10): 1274-1276.

62- Zhang Y, Chen B, Xu Z, Shi Z, Chen S, Huang X, et al. Involvement of reactive oxygen species in endosperm cap weakening and embryo elongation growth during lettuce seed germination. J Exp Bot. 2014; http://dx.doi.org/10.1093/jxb/eru167.

63- Kawano T. Roles of the reactive oxygen speciesgenerating peroxidase reactions in plant defense and growth induction. Plant Cell Rep. 2003; 21: 829837.

64- Džamić AM, Soković MD, Ristić MS, Novaković M, Grujić-Jovanović S, Tešević V, Marin PD. Antifungal and antioxidant activity of Mentha longifolia (L.) Hudson (Lamiaceae) essential oil. Botanica Serbica. 2010; 34(1): 57-61.

65- Bahtiti NHAl. Biological activities of the methanol extract of cultivated jordanian fresh and dried mint species (Mentha Longifolia). International Journal of Research Studies in Biosciences. 2015; 3(1): $205-$ 210.

66- Bansal N, Kanwar SS. Peroxidase(s) in environment protection. The Scientific World Journal. 2013; Article ID 714639, http://dx.doi.org/10.1155/2013/714639.

67- Del Rio LA, Sandalio LM, Corpas FJ, RomeroPuertas MC, Palma JM. Peroxisome as a acellular source of ROS signal molecule. In: Del Rio LA, Puppo A, editors. Reactive oxygen species in plant signaling. Springer. 2009. p. 100-102.

68- Vara Prasad MN, De Oliveira Freitas HM. Metal hyperaccumulation in plants - Biodiversity prospecting for phytoremediation technology. Electron J Biotechn. 2003; 6(3): 285-305.

69- Dizengremel P, Le Thiec D, Hasenfratz-Sauder MP, Vaultier MN, Bagard M, Jolivet Y. Metabolicdependent changes in plant cell redox power after ozone exposure. Plant Biol. Special Issue: Plant Functioning in a Changing Global Environment. 2009; 11(s1): 35-42. 
70- O'leary B, Park J, Plaxton WC. The remarkable diversity of plant PEPC (phosphoenolpyruvate carboxylase): recent insights into the physiological functions and post-translational controls of nonphotosynthetic PEPCs. Biochem J. 2011; 436: 15-34.

71- Kaczyńska G, Borowik A, Wyszkowska J. Soil dehydrogenases as an indicator of contamination of the environment with petroleum products. Water Air Soil Pollut. 2015; 226: 372.

72- Kumar S, Chaudhuri S, Maiti SK. Soil dehydrogenase enzyme activity, in Natural and mine soil - a review. Middle-East Journal of Scientific Research. 2013; 13 (7): 898-906.

73- Subhani A, Changyong H, Zhengmiao Y, Min L, Elghamry A. Impact of soil environment and agronomic practices on microbial/dehydrogenase enzyme activity in soil - A Review. Pakistan Journal of Biological Sciences. 2001; 4: 333-338.

74- Ghaly A, Mahmoud N. Optimum conditions for measuring dehydrogenase activity of Aspergillus niger using TTC. American Journal of Biochemistry \& Biotechnology. 2006; 2: 186-194.

75- Levyk V, Maryskevych O, Brzezińska M, Włodarczyk T. Dehydrogenase activity of technogenic soils of former sulphur mines (Yvaoriv and Nemyriv, Ukraine). Int Agrophys. 2007; 21: 255260.

76- Trasar-Cepeda C, Gil-Sotres F, Leiros M. Thermodynamic parameters of enzymes in grassland soils from Galicia, NW Spain. Soil Biol Biochem. 2007; 39: 311-319.

77- Xie W, Zhou J, Wang H, Chen X, Lu Z, Yu J, Chen $X$. Short-term effects of copper, cadmium and cypermethrin on dehydrogenase activity and microbial functional diversity in soils after long-term mineral or organic fertilization. Agriculture, Ecosystems \& Environment. 2009; 129: 450-456.

78- Błońska E. Enzyme activity in forest peat soils. Folia Forestalia Polonica. 2010; 52: 20-25.

79- Fernandez-Calviño D, Soler-Rovira P, Polo A, DiazRaviña M, Arias-Estevez M, Plaza C. Enzyme activities, In Vineyard soils long-term treated with copper-based fungicides. Soil Biol Biochem. 2010; 42: 2119-2127.

80- Macci C, Doni S, Peruzzi E, Masciandro G, Mennone C, Ceccanti B. Almond tree and organic fertilization for soil quality improvement in southern Italy. J Environ Manage. 2012; 95: 215-222.

81- Ciornea E, Dumitru G, Dumitrascu S. The enzymatic activity of soil's dehydrogenases in Tasca and Tarcau areas. An. Şt. Univ. ,Alexandru Ioan Cuza” Iaşi, s. II a Genetică şi Biologie Moleculară. 2014; 15(2): 6570.

82- Park K, Jung W, Park J. Decontamination of uranium-contaminated soil sand using supercritical $\mathrm{CO}_{2}$ with a $\mathrm{TBP}-\mathrm{HNO}_{3}$ complex. Metals. 2015; 5: 1788-1798.
83- Dick RP, Breakwill D, Turco R. Soil enzymes activities and biodiversity measurements as integrating biological indicators. In: Doran JW, Jones AJ editors. Handbook of methods for assessment of soil quality. Ed. Soil Sci. Soc. Am: Madison. 1996. p. 247-272.

84- Agnelli A, Ascher J, Corti G, Ceccechrini M, Nannipieri P, Pietramellara G. Distribution of microbial communities in a forest soil profile investigated by microbial biomass, soil respiration and DGGE of total and extracellular DNA. Soil Biol Biochem. 2004; 36: 859-868.

85- Wolińska A. Dehydrogenase activity of soil microorganisms and oxygen availability during reoxidation process of the selected mineral soils from Poland. Acta Agrophys. 2010; 180-188.

86- Wolińska A, Stępniewska Z. Dehydrogenase activity in the soil environment. In: Canuto RA, editor. Biochemistry, Genetics and Molecular Biology "Dehydrogenases". 2012. p. 183-210.

87- Irha N, Slet J, Petersell V. Effect of heavy metals and $\mathrm{PAH}$ on soil assessed via dehydrogenase assay. Environ Int. 2003; 28(8): 779-782.
Received: January 15, 2016; Accepted: May 11, 2016 